資 料

\title{
我が国におけるノロウイルス食中毒，感染症の現状
}

\author{
野田 衛*
}

国立医薬品食品衛生研究所

\section{Current Status of Norovirus Infections in Japan}

\author{
Mamoru NODA*
}

National Institute of Health Sciences

\begin{abstract}
Summary
Norovirus is a genus in caliciviridae and includes a single species called norwalk virus. Human noroviruses are major pathogens of acute gastroenteritis, especially in winter, and are transmitted via a fecal-oral route, either by ingestion of food or water contaminated with feces or by direct or indirect contact with the vomit or feces of an infected person. The number of patients infected with noroviruses has accounted for half of all of the patients with food poisoning in recent years in Japan. Epidemiological features of norovirus outbreaks have changed in recent years : for instance, foodborne outbreaks associated with foods contaminated from an infected food handler other than bivalve mollusks such as oysters have increased, and outbreaks in elderly facilities have increased. New variant strains of G II .4 have emerged every year or every few years because the genome of G II .4 changes more frequently than the genomes of other genotypes. The emergence of G II .4 2006b and G II .4 Sydney 2012 variants led to many outbreaks in the 2006/07 and 2012/13 seasons, respectively. Point mutations and recombinations in the genome may be responsible for the evolution of noroviruses. Noroviruses have been detected not only in humans but also in animals such as cattle, pigs and mice. There is no direct evidence that noroviruses cause zoonotic transmission, but some reports have indicated that possibility. There is a need for an approach from the viewpoint of zoonosis in the future studies.
\end{abstract}

\section{1. はじめに}

ノロウイルスは, ヒトにおける散発性および集団の胃腸 炎並びに食中毒の主要原因ウイルスであり, 主に冬期を中 心に流行がみられる。特に近年は, 高齢者施設での死亡例 を伴う集団感染事例や大規模食中毒事件が発生するなど, 多くの健康被害をもたらしており, 公衆衛生上また食品衛 生上重要なウイルスとして位置づけられている。近年では 2006/07 シーズンおよび 2012/13 シーズンに大流行がみら れたが，その背景には新しい变異株の出現があることが分 子疫学的研究で示されている。ノロウイルスの遺伝学的な 進化には, 点変異の蓄積および遺伝子組み換えが重要な役 割をはたしている。一方, ノロウイルスはヒト以外に, 牛,

\section{連絡先: 野田 衛*}

国立医薬品食品衛生研究所食品衛生管理部第四室 干158-8501 東京都世田谷区上用賀 1-18-1 Tel : 03-3700-9104 (直通) ; Fax : 03-3700-9527

E-mail :mamorunoda@nihs.go.jp
豚，マウスなどの動物からも検出されている。それらの遺 伝学的な研究からヒトノロウイルスとの関連性を示す株も 検出され, 人獣共通感染症の側面からも注目されている。

本稿では, ヒトノロウイルスを中心として, 近年の流行 状況とそのウイルス学的な背景について概観するととも に，動物由来ノロウイルスについても触れる。

\section{2. ノロウイルスの構造と特徵}

ノロウイルスはカリシウイルス科に属する，エンベロー プを持たない直径約 30〜 $40 \mathrm{~nm}$ の球形ウイルスである。ノ ロウイルスは分類学上属名にあたり, 現在ノーウォークウ イルス種の 1 種のみが含まれている (International Committee on Taxonomy of Viruses (ICTV), http://www.ictvonline. org.)。微生物は種名で呼ばれることが一般的であるが, ノ ロウイルス属にはノーウォークウイルス種のみが含まれる こと, および最初に報告されたノロウイルスの株名がノー ウォークウイルスであり, 種名と株名が混乱しやすいこと などから，ノロウイルスと呼ばれる場合が多い。ノロウイ 
ルスのゲノムは, 約 $7.6 \mathrm{~kb}$ の 1 本鎖 $(+)$ RNA で ${ }^{60)}$, ゲノ ムの相同性に基づきゲノグループ 1 (GI) から GVの 5 遺 伝子群に分類されている ${ }^{65)}$ 。このうち，ヒトに感染するノ ロウイルスは G I, G II および G IV の 3 種類の遺伝子群に 属し, 感染症事例や食中毒事例から検出されるノロウイル スの大半は G I と G II に属する。マウスノロウイルスは G $\mathrm{V}$ に属し, ウシから検出されたノロウイルスは $\mathrm{G}$ III に属す る。G I および G II の両遺伝子群は, さらに異なる遺伝子 型に分類され, 異なる遺伝子型は基本的に抗原性が異な る ${ }^{17)}$ 。ノロウイルスの遺伝子型分類に関しては, 世界的に 統一した分類法はこれまでなく，我が国では ORF2（VP1） の $\mathrm{N}$ 末端付近（N/S 領域）の部分塩基配列の相同性に基づ く分類法に従い遺伝子型別されていた (http://idsc.nih.go.jp/ pathogen/refer/noro-kaisetu1.html)。昨年, 世界的に統一さ

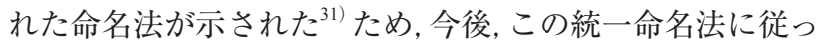
た遺伝子型名が使用されるようになると予想されるが，地 方衛生研究所等で検出された病原体の集計を行っている国 立感染症研究所感染症疫学センターの報告システム上の問 題や地方衛生研究所での検査法上の問題等もあり, しばら くは混同した状況が続くと思われる。

ノロウイルスのゲノムには, 3 つの Open reading frame (ORF，読み取り枠）すなわち，ORF1，ORF2 および ORF3 が存在する ${ }^{60)}$ 。ORF1には, RNA 依存性 RNA ポリメラーゼ, 蛋白質分解酥素など, ウイルスの増殖に必須な 6〜 7 種類 の非構造蛋白質 ${ }^{1)}$ が，ORF2 には主要なウイルス構造蛋白 質である VP1 ${ }^{24)}$ が, ORF3にはマイナーなウイルス構造蛋 白質であるVP2 ${ }^{13)}$ がそれぞれコードされている。VP1 は， カプシド蛋白質の基底部をなす N-terminal/Shell $(\mathrm{N} / \mathrm{S})$ 領 域と突出した部位である Protruding $(\mathrm{P})$ 領域に分けれ, P 領域はさらにP1 領域と P2 領域に分けられている ${ }^{45)}$ 。 P2 領域はウイルス粒子の最も外側に位置し, そのアミノ酸配 列は多様性に富み, ノロウイルスの抗原性に関連する ${ }^{177}$ 。 VP1 分子は 2 量体を形成し, それらが 90 対（180 分子） 集合し, ウイルス粒子を構成している ${ }^{45)}$ 。2 量体から形成 されるポケット構造の部分は, ノロウイルスが腸管上皮細 胞に付着する際に利用していると考えられている糖鎖抗原 (組織血液型抗原) の結合部位となっている 血液型抗原とはヒトの $\mathrm{ABO}$ 式血液型, ルイス式血液型に 関与する糖鎖抗原 ${ }^{18)}$ で, 赤血球のほか, 胃, 腸, 膵臓な ど多くの蔵器や唾液などで発現している ${ }^{46)}$ 。さらに, 各種 の組織血液型抗原との結合性はノロウイルスの種類により 違いが認められている22)。一方，ノロウイルスは細胞への 吸着, 侵入に組織血液型抗原を利用していないとする報告 もある ${ }^{36)}$ 。

\section{3. ノロウイルス感染の症状と感染経路}

ノロウイルス感染に打ける潜伏期間（感染から発症まで の時間）は 24〜 48 時間で，吐き気，嘔吐，下痢，腹痛が 主な症状で, 発熱は一般的に軽度 $\left(37 \sim 38^{\circ} \mathrm{C}\right)$ である。特 に, 突発的な吐き気や嘔吐が特徵的で, 室内等で嘔吐をし て，環境を污染する原因となっている。通常は，これらの 症状が 1〜2 日続いた後, 治瘉し, 後遺症はない。感染し ても症状がでない不顕性感染を起こす場合や軽い風邪のよ うな症状の場合もある。一方, 高齢者や乳幼児では, 嘔吐 物による窒息や誤嚥性肺炎による死亡例がまれに認められ る。症状は一般的に数日で快方に向かうが, 糞便中には通 常は 1 週間程度, 長い場合は 1 か月以上に渡りウイルス粒 子の排出が続く。そのため, 回復後も糞便中のウイルス粒 子が手指に付着するとドアノブ等を污染して, 二次感染や 集団感染の感染源となる。

ノロウイルスの感染経路は経口感染であり, 食品媒介感 染 (食中毒), 接触感染抒よび飛沫感染・塵埃感染に大別 される。

食品媒介感染はいわゆる食中毒で，ノロウイルスに污染 された食品や水を摃取することによって起こる。食品の污 染経路により，ノロウイルスに污染された食品（カキ等の 二枚貝）を生または加熱不十分の状態で食べる場合，ノ口 ウイルスに感染した調理従事者の手指等を介して調理中に 食品を污染し，その污染食品を摂取する場合の 2 つに分け られる。

接触感染は, ノロウイルスに感染した乳幼児の共便や嘔 吐物に直接触れ，手指等を介してウイルスが口から入る場 合の他，感染した人の手指等に付着したウイルスがドア， ブ等の環境を污染し，それに接触した手指等を介してウイ ルスが口から入る場合がある。

飛沫感染や塵埃感染は主に嘔吐物を介して起こる。患者 の煰吐物が飛散し, その飛沫 (ノロウイルスを含んだ小さ な水滴）が口から入る場合（飛沫感染）や床などに污染し た嘔吐物の処理が不十分な場合, 乾燥してチリやほこり(塵 埃）となり空気中に浮遊し，それらに含まれるウイルス粒 子が経口的に取り込まれる場合がある。

\section{4. ノロウイルス食中毒, 感染症の現状}

\section{（1）感染性胃腸炎の原因としてのノロウイルスの流行状 況}

ノロウイルスの感染者数は, 散発発生, 集団感染症, 食 中毒を問わず年間数百万人程度であると推定されている37)。 これは年間のノロウイルス食中毒患者報告数の数百倍に相 当する。感染者の多くは乳幼児, 小児の子供であり, 冬期 を中心に流行する。感染症発生動向調査の「感染性胃腸炎」 


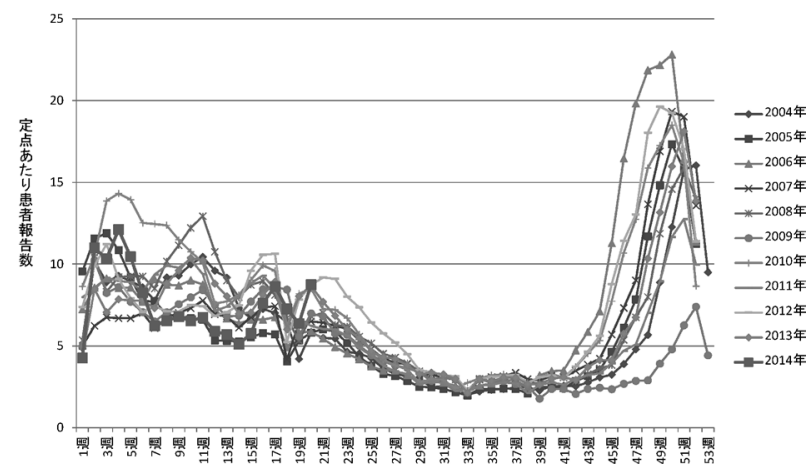

国立感染症研究所感染症疫学センターの情報を基に集計

困 1 感染性胃腸炎報告数

報告数から発生状況をみると, 2006/07 シーズンに過去最 大の報告数が記録された。2012/13 シーズンは, 2006/07 シー ズンに次ぐ流行がみられた（図 1)。

感染性胃腸炎の報告数は国立感染症研究所感染症疫学セ ンターのホームページに全国のデータとして掲載されてい る他, 多くの自治体のホームページにも地域ごとの患者報 告数が掲載されている。「感染性胃腸炎」報告数はノロウ イルス患者発生数を示すデータとして, しばしば利用され ているが, ノロウイルス以外に, ロタウイルス, サポウイ ルス, アストロウイルス, アデノウイルスなどの他のウイ ルスや細菌なども原因となり, 必ずしもノロウイルスによ る感染性胃腸炎を意味しないことを理解しておくことが肝 要である。

\section{（2）ノロウイルス食中毒}

ノロウイルスによる食中毒は, 感染性胃腸炎の多発時期 と一致して, 11 月から増加し，12月をピークとして， 3 月まで多く発生している。近年のノロウイルスの食中毒は 夏場を含み通年性に発生がみられる。感染性胃腸炎の発生 状況と一致し, 2006/07 シーズン, 2012/13 シーズンはノ ロウイルス食中毒が多発した（図 2)。特に, 2006/07 シー ズンは患者数も多く, かつ, 1 事例当たりの患者数も多い 傾向にあった。

ノロウイルス食中毒の原因食品をみると, 従来ノロウイ ルス食中毒の代名詞であったカキによる食中毒は全体の約 $10 \%$ 程度を占めるに過ぎない ${ }^{30)}$ 。ただし, 原因食品不明と される事例に含まれる場合もあり, 実際はもう少し高い割 合を占めると考えられる。現在, 生食用カキには, ウイル ス学的な規格基準は設定されておらず, ウイルス学的な安 全性が担保されている訳ではない。カキのノロウイルス対 策を推進する一方,「十分に加熱して食べれば安全性に問 題はない。しかし, 生（あるいは加熱不足）で食べれば健 康被害の恐れがある」ことを，日常的にリスクコミニケー ションすることが重要である。

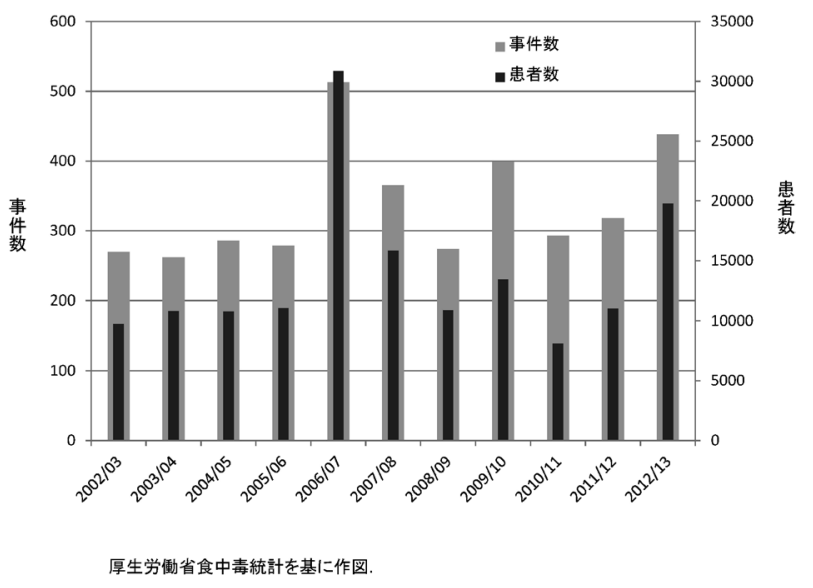

図 2 流行期別ノロウイルス食中毒発生状況

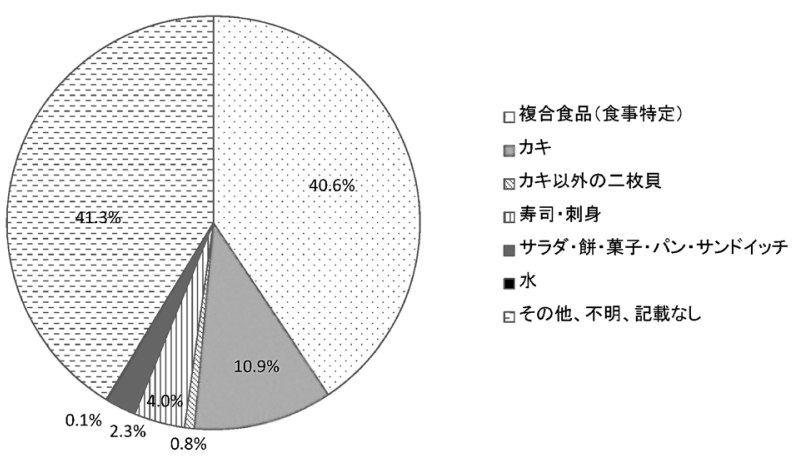

図 3 ノロウイルス食中毒における原因食品の割合

一方, 現在のノロウイルス食中毒は, 食品取扱者からの 食品の二次污染を原因とする事例が大半を占めている。盛 りつけ時にも食品污染が起こるため, 非加熱食品のみなら ず加熱食品を含め多種多様な食品が原因となっている。ノ ロウイルス食中毒の特徴として, 仕出し弁当, 宴会料理な ど食事として特定された事件を含め原因食品が不明な事例 が $80 \%$ 以上を占めている（図 3)。原因食品が特定された 事例では, 寿司, 刺身, サラダ, 餅, 菓子（おはぎ, ケー キなど), パン, サンドイッチ等による事例が報告されて いる。

ノロウイルス食中毒事例は, 飲食店, 旅館, 仕出屋, 事 業場, 病院, 学校など様々な施設で発生している。飲食店 での発生が半数以上を占めるが, 大規模な事例は仕出し弁 当が原因と推定されるノロウイルスによる食中毒事件で多 くみられる ${ }^{30)}$ 。

\section{（3）ノロウイルス集団発生}

ノロウイルスによる集団感染症は, 従来, 保育園, 小学 校など子供の集団施設での発生が主体であったが，2003/04 


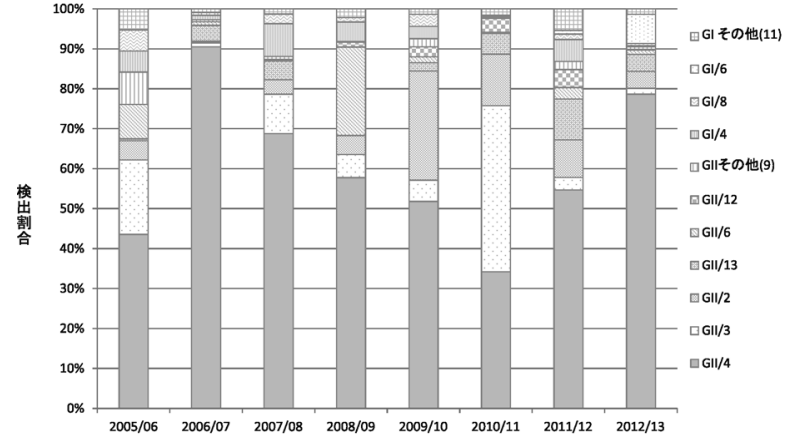

国立感染症研究所感染症疫学センターに報告された病原微生物検出情報のデータを基に作图(2013年9月25日現在)

図 4 流行期別検出ノロウイルスの遺伝子型

シーズン以降, 高齢者施設での集団発生が顕在化してい る ${ }^{61)}$ 。高齢者においては, 嘔吐物による誤與性肺炎や窒息 などによる死亡例がみられることから，インフルエンザと ともに冬期の感染症として重要視する必要がある。高齢者 に押いては, 抵抗力が弱いことや手洗い等の日常の衛生管 理の実施が困難であることに加え，年齢が高くなるにつれ 湢吐のみが症状としてみられる報告もあり, 初発事例がノ ロウイルスによると認識されにくいことも, 高齢者施設に おける集団発生の制御が困難な原因となっている。

\section{5. ノロウイルスの遺伝子型と流行}

近年の分子疫学的な研究により, 流行規模には原因と なったノロウイルスの遺伝子型が関係することが示されて いる。2005/06 シーズンから 2012/13 シーズンに検出され たノロウイルスの遺伝子型をみると（図 4), ノロウイル スが大流行し, 集団食中毒が多発した 2006/07 シーズンや 2012/13 シーズン（図 1，2）には, 遺伝子型 G II .4 の占め る割合が高いことがわかる。この背景には, 2006/07 シー ズンには G II .4 2006b，2012/13 シーズンには G II.4 Sydney 2012 と呼ばれる新しい変異株が出現し, 大流行したこと がある。また，吉澄らの報告にみられるように，近年の高 齢者施設での集団発生の増加と G II.4 の流行は見事に呼応 している ${ }^{61)}$ 。

以上のように, 近年の高齢者施設での集団発生の顕在化 や食中毒事例の多発などのノロウイルス感染症の疫学的な 変化の背景には, ノロウイルス流行株の変化, とりわけ $\mathrm{G}$ II .4 の流行が関連していると考えられる ${ }^{39)}$ 。

\section{6. ノロウイルスの変異}

\section{（1）点変異}

ノロウイルスは 1 本鎖 RNA をゲノムとしてもつが, RNA 依存性 RNA ポリメラーゼに校正機能はなく, 容易に
点変異を起こす。この複製ミスによる変異はすべてのノロ ウイルスで生じるが，遺伝子型 G II .4 において特に顕著で ある ${ }^{2,4,64)}$ 。遺伝子の変異に基づく新しい変異株の出現は必 ずしも流行に影響を及ぼすものではないが，大流行の背景 に新しい変異株の出現が観察されたケースがこれまで少な からず報告されている。その典型的な事例が， G II .4 2006b 変異株による2006/07 シーズンの世界的な大流行であ $\eta^{12,20,34,47)}$, G II .4 Sydney 2012 変異株によるそれに次ぐ世 界的な流行である ${ }^{10,51,53)}$ 。これらの大流行を起こした G II .4 2006b 変異株や G II .4 Sydney 2012 変異株について, P2 ド メインのアミノ酸配列をみると, 糖鎖抗原結合部位近傍の アミノ酸に変異がみられる ${ }^{35)}$ 。そのため, これらのアミノ 酸の変化により, 過去にノロウイルス G II.4に感染して得 た抗体が，粒子への結合能力を失い，過去に G II.4 に感染 した個体でも感染の成立が容易となり，患者が拡大したも のと考えられる。

\section{（2）遺伝子組み換え}

一方，ノロウイルスには，ORF1 と ORF2 の間（ジャン クション領域）で遺伝子組み換えを起こした組み換え型の ウイルスが数多く検出されている ${ }^{11,23,28,35,43,44)}$ 。ノロウイル スの研究者で組織されるノロウイルスサイエンティフィッ クコミッティーは，この組み換え型をキメラウイルスと呼 ぶように推奨している。キメラウイルスは, 同じ遺伝子群 に属するウイルス同士に由来する場合が多いが，異なる遺 伝子群のウイルスから成るキメラウイルスも報告されてい $3^{38,43)}$ 。

ORF1 と ORF2 の間で遺伝子組み換えが頻繁に起こる理 由については明らかにされていないが, ORF1 と ORF2の ジャンクション領域はノロウイルスの全ゲノムの中で最も 相同性が高い部位であること ${ }^{25)}$, また, 増殖時に子孫ウイル スの構造蛋白質を効率的に合成するために, ORF2 と ORF3

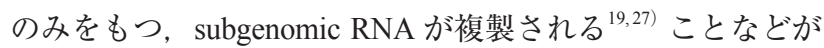
関連していると推察される。ORF2 の $5^{\prime}$ 末端のすぐ上流に はゲノムの $5^{\prime}$ 末端と同じ繰り返し配列が存在している ${ }^{60)}$ ことも，この部位で遺伝子組み換えを起こしやすい要因と なっているのかも知れない。

\section{7. 動物のノロウイルス}

\section{（1） ウシノロウイルス，ブタノロウイルス}

ウシノロウイルスは遺伝子群 GIIIに属し ${ }^{65)}$, Jena agent を代表株とする GIII.1 および Newbury agent-2 を代表株と する GIII.2に分類されている ${ }^{42)}$ 。Jena agent はドイッ ${ }^{15)}$, Newbury agent-2 はイギリス ${ }^{59)}$ のウシから検出され，両者 の抗原性は異なる ${ }^{40)}$ 。 Newbury agent-2 とともに検出され た Newbury agent-1 はカリシウイルス科に属するものの既 知のウイルスとは異なることから, Nebraska 株 ${ }^{48)}$ ととも 
に，新しい属（Becovirusまたは Nabovirus）に分類されて いる ${ }^{41)}$ 。

ウシ糞便等からのウイルス検出および抗体保有調査か ら, GIII.2 に属するウイルスがウシにおいて広く蔓延して

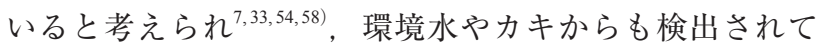
いる ${ }^{62)}$ 。

Newbury agent-2 に感染すると, 下痢, 食欲不振, 小腸 の上部から中部にかけての絨毛の短小化と平滑化の病態を 示す ${ }^{16)}$ 。感染後 24 時間で症状はピークとなり，10日目ま で持続する。ウイルスは感染後 1〜4 日目まで, 腸内容物 や便から検出される。

現在ノロウイルスが人獣共通感染症であることを示す直 接的な根拠はないが, 前述のようにノロウイルスは点変異 や遺伝子組み換えを頻繁に引き起こすことから, その可能 性を否定できるものではない。ヒトにおけるウシノロウイ ルス G III.2 に対する抗体調査では抗体保有率は $22^{57)} \sim 26.7$ $\%^{55)}$ と報告されている。Widdowson ${ }^{57)}$ によれば,一般 人が $20 \%$, 獣医師が $28 \%$ で, 獣医師の抗体陽性率が有意 (P =0.03）に高く, ウシノロウイルス抗体陽性者のうち, 26 $\%$ はヒトノロウイルスよりもウシノロウイルスに強く反 応した。ウシノロウイルスのレセプターは, 動物では一般 的な糖鎖構造である $\alpha \mathrm{GAL}(\mathrm{Gal} \alpha 1-3 \mathrm{Gal} \beta$ 1-4GlcNAc）で あることがVLPを用いた実験で示唆されている ${ }^{63)} 。 a \mathrm{GAL}$ を持つ糖鎖はヒトでは発現していない。ブタにおいては, ウシノロウイルス VLP の腸管への結合が示されているが, 腸管上皮細胞には $\alpha$ GAL は発現しておらず，血管内皮細 胞等限られた細胞で発現している ${ }^{63)}$ 。これらのことから, ウシノロウイルスがヒトやブタに直接感染する可能性は高 くないと思われる。一方，GIII.2のVLPを用いた結合実 験では， $a \mathrm{GAL}$ だけでなく，シアル酸にも結合すること が示されており ${ }^{32)}$, 必ずしも感染に $\alpha \mathrm{Gal}$ を持つ糖鎖を必 要としない可能性もある。

ブタからのノロウイルスの検出は我が国において最初に 報告された ${ }^{50)}$ 。ブタから検出されるノロウイルスは遺伝子 群 G II に属し，ヒトノロウイルスに近縁であるが，ヒトか ら検出される遺伝子型とは異なる ${ }^{56)}$ 。ブタからのノロウイ ルス検出率は高くなく $0.4 \%{ }^{50)}$ 程度である。一方, ブタに おけるブタ由来 G II ノロウイルスに対する抗体保有率は米

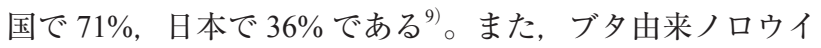
ルスはブタの感染実験で増殖が確認されている。これらの 報告から, ブタ由来ノロウイルス G II はヒトノロウイルス とは異なり, ブタ固有のウイルスである可能性が高いが, ブタにおける病原性, ヒトへの伝搬の可能性など不明な部 分が多い。

一方，ノトバイオートのウシやブタはヒトノロウイルス の G II.4 に感染し, 下痢や腸病変を呈する ${ }^{6,49)}$ 。Souza ら
の報告では ${ }^{49)}$ ，G II .4 に感染した 5 例のウシはすべて下痢 を呈し, 十二指腸や空腸に, 絨毛の脱落に特徴付けられる 重篤な病変が観察されている。

\section{（2）ネズミノロウイルス}

遺伝子群 $\mathrm{GV}$ に分類される ${ }^{65)}$ ネズミノロウイルスは 2003 年に米国で初めて発見された ${ }^{29)}$ 。ネズミノロウイル スは, 当初免疫系ノックアウトマウスから検出されたこと から，特殊なウイルスとも考えられたが，その後一般的な 実験用マウスや野生のマウスからの検出や抗体保有状況に 関する報告が相次ぎ, 14,21,29)， ネズミに広く分布している ものと考えられる。ネズミノロウイルスは 8 週間にわたり 粪便中に排出され，持続感染を起こすことが示されてい $ろ^{21)}$ 。遺伝子的にも多様性が認められ, Farkas ら ${ }^{8)}$ はハツ カネズミ(Mus musculus) から検出されるネズミノロウイ ルスを GV.1, アカネズミ(Apodemus) から検出されるネ ズミノロウイルスを GV.2 に分類している。

ネズミノロウイルスはノロウイルス属に属するウイルス のうち, 唯一培養細胞での増殖が可能で, ヒトノロウイル スの代替ウイルスとして, 環境中での生存性試験, 不活化 法や消毒薬の評価試験に広く利用されている他, ウイルス の増殖機構の解明, 抗ウイルス薬の開発などに大きく貢献 するものと思われる。

\section{8. おわりに}

以上, ヒトノロウイルスの流行状況およびその背景とな るノロウイルスの特徵並びにウシ，マウス等の動物のノロ ウイルスついて概説した。ヒトノロウイルスはいまだ増殖 系が確立されておらず, 疫学的なデー夕は蓄積されつつあ るものの, ウイルス学的性状に関しては不明な部分が多く 残されている。また，消毒効果判定など予防に必要なデー 夕も得ることができず, 公衆衛生上また食品衛生上の大き な支障となっている。ヒトノロウイルスの培養系の確立が 急務の課題である。一方, 動物ノロウイルスについても, 一般に特段重篤な症状を呈することはないこともあり，こ れまで十分に研究されているとは言い難く, ノロウイルス が人獣共通感染を起こすか否かに関しても不明な部分が多 い。本概説が獣医領域の諸先生方の興味を引き，今後本分 野での研究が進展するきっかけとなれば幸いである。

\section{参考文献}

1) Belliot, G. et al. : In vitro proteolytic processing of the MD145 norovirus ORF1 nonstructural polyprotein yields stable precursors and products similar to those detected in calicivirus-infected cells. J. Virol., 77, 10957-10974, 2003.

2) Bok, K. et al. : Evolutionary dynamics of G II .4 noroviruses over a 34-year period. J. Virol., 83, 11890-11901, 
2009.

3) $\mathrm{Bu}, \mathrm{W}$. et al. : Structural basis for the receptor binding specificity of Norwalk virus. J. Virol., 82, 5340-5347, 2008.

4) Bull, R.A. et al. : Rapid evolution of pandemic noroviruses of the G II .4 lineage. PLoS Pathog., 6, e1000831, 2010.

5) Cao, S. et al. : Structural basis for the recognition of blood group trisaccharides by norovirus. J. Virol., 81, 5949-5957, 2007.

6) Cheetham, S. et al. : Pathogenesis of a genogroup II human norovirus in gnotobiotic pigs. J. Virol., 80, 1037210381, 2006.

7) Deng, Y. et al. : Studies of epidemiology and seroprevalence of bovine noroviruses in Germany. J. Clin. Microbiol., 41, 2300-2305, 2003.

8) Farkas, T. et al. : Molecular detection of murine noroviruses in laboratory and wild mice. Vet. Microbiol., 160, 463467, 2012.

9) Farkas, T. et al. : Seroprevalence of noroviruses in swine. J. Clin. Microbiol., 43, 657-661, 2005.

10) Fonager, J. Barzinci, S. and Fischer, T.K. : Emergence of a new recombinant Sydney 2012 norovirus variant in Denmark, 26 December 2012 to 22 March 2013. Euro. Surveill., 18, pii : 20506, 2013.

11) Fukuda, S. et al. : Recombinant norovirus implicated in gastroenteritis outbreaks in Hiroshima Prefecture, Japan. J. Med. Virol., 80, 921-928, 2008.

12) Gallimore, C.I. et al. : Inter-seasonal diversity of norovirus genotypes : emergence and selection of virus variants. Arch. Virol., 152, 1295-1303, 2007.

13) Glass, P.J. et al. : Norwalk virus open reading frame 3 encodes a minor structural protein. J. Virol., 74, 6581$6591,2000$.

14) Goto, K. et al. : Molecular detection of murine norovirus from experimentally and spontaneously infected mice. Exp. Anim., 58, 135-140, 2009.

15) Günther, H. and Otto, P. : Diarrhea in young calves. 7. "Zackenvirus" (Jena agent 117/80) — a new diarrhea pathogen in calves (in German). Arch. Exp. Veterinarmed., 41, 934-938, 1987.

16) Hall, G.A. et al. : Lesions of gnotobiotic calves experimentally infected with a calicivirus-like (Newbury) agent. Vet. Pathol., 21, 208-215, 1984.

17) Hansman, G.S. et al. : Genetic and antigenic diversity among noroviruses. J. Gen. Virol., 87, 909-919, 2006.

18) Henry, S.M. : Review : phenotyping for Lewis and secretor histo-blood group antigens. Immunohematology., 12, 51$61(1996)$

19) Herbert, T.P., Brierley, I. and Brown, T.D. : Detection of the ORF3 polypeptide of feline calicivirus in infected cells and evidence for its expression from a single, functionally bicistronic, subgenomic mRNA. J. Gen. Virol., 77, 123127, 1996.

20) Ho, E.C. et al. : Atypical norovirus epidemic in Hong Kong during summer of 2006 caused by a new genogroup II /4 variant. J. Clin. Microbiol., 45, 2205-2211, 2007.

21) Hsu, C.C. et al. : Persistent infection with and serologic cross-reactivity of three novel murine noroviruses. Comp. Med., 56, 247-251, 2006.

22) Huang, P. et al. : Norovirus and histo-blood group antigens : demonstration of a wide spectrum of strain specificities and classification of two major binding groups among multiple binding patterns. J. Virol., 79, 6714-6722, 2005.

23) Jiang, $X$. et al. : Characterization of a novel human calicivirus that may be a naturally occurring recombinant. Arch. Virol., 144, 2377-2387, 1999.

24) Jiang, $X$. et al. : Expression, self-assembly, and antigenicity of the Norwalk virus capsid protein. J. Virol., 66, 65276532, 1992.

25) Kageyama, T. et al. : Broadly reactive and highly sensitive assay for Norwalk-like viruses based on real-time quantitative reverse transcription-PCR. J. Clin. Microbiol., 41, 1548-1557, 2003.

26) Karst, S.M. et al. : STAT1-dependent innate immunity to a Norwalk-like virus. Science, 299, 1575-1578, 2003.

27) Katayama, K. et al. : Investigation of norovirus replication in a human cell line. Arch. Virol., 151, 1291-1308, 2006.

28) Katayama, K. et al. : Phylogenetic analysis of the complete genome of 18 Norwalk-like viruses. Virology, 299, 225$239,2002$.

29) Kim, J.R. et al. : Prevalence of murine norovirus infection in Korean laboratory animal facilities. J. Vet. Med. Sci., 73, 687-691, 2011.

30）国立感染症研究所：ノロウイルス食中毒, 2011 年現在. IASR, 32, 352-353, 2011.

31) Kroneman, A. et al. : Proposal for a unified norovirus nomenclature and genotyping. Arch. Virol., 158, 2059-2068, 2013.

32) Mauroy, A. et al. : Alternative attachment factors and internalization pathways for G III. 2 bovine noroviruses. J. Gen. Virol., 92, 1398-1409, 2011.

33) Milnes, A.S. et al. : Retrospective study of noroviruses in 
samples of diarrhoea from cattle, using the Veterinary Laboratories Agency's Farmfile database. Vet. Rec., 160, 326-330, 2007.

34) Motomura, K. et al. : Identification of monomorphic and divergent haplotypes in the 2006-2007 norovirus G II /4 epidemic population by genomewide tracing of evolutionary history. J. Virol., 82, 11247-11262, 2008.

35) Motomura, K. et al. : Divergent evolution of norovirus G II /4 by genome recombination from May 2006 to February 2009 in Japan. J. Virol., 84, 8085-8097, 2010.

36) Murakami, K. et al. : Norovirus binding to intestinal epithelial cells is independent of histo-blood group antigens. PLoS One. 8, e66534. doi : 10.1371/journal.pone.0066534, 2013.

37）内閣府食品安全委員会 : 食品健康影響評価のためのリ スクプロファイルおよび今後の課題〜食品中のノロウ イルス〜. Available at : http://www.fsc.go.jp/sonota/risk_ profile/risk_norovirus.pdf

38) Nayak, M.K. et al. : Detection of a novel intergenogroup recombinant norovirus from Kolkata, India. Virology., 377, 117-123, 2008.

39）野田 衛, 山下和予：2006 年の早期流行と多発の要 因. 食品衛生研究，57，10-18，2007.

40) Oliver, S.L. et al. : Genotype 1 and genotype 2 bovine noroviruses are antigenically distinct but share a crossreactive epitope with human noroviruses. J. Clin. Microbiol., 44, 992-998, 2006.

41) Oliver, S.L. et al. : Genomic characterization of the unclassified bovine enteric virus Newbury agent-1 (Newbury1) endorses a new genus in the family Caliciviridae. Virology, 350, 240-250, 2006.

42) Oliver, S.L. et al. : Molecular characterization of bovine enteric caliciviruses : a distinct third genogroup of noroviruses (Norwalk-like viruses) unlikely to be of risk to humans. J. Virol., 77, 2789-2798, 2003.

43) Phan, T.G. et al. : Genetic heterogeneity, evolution, and recombination in noroviruses. J. Med. Virol., 79, 13881400, 2007.

44) Phan, T.G. et al. : Multiple recombinant noroviruses in Japan. Clin. Lab., 53, 567-570, 2007.

45) Prasad, B.V. et al. : X-ray crystallographic structure of the Norwalk virus capsid. Science, 286, 287-290, 1999.

46) Ravn, V. and Dabelsteen, E. : Tissue distribution of histoblood group antigens. APMIS, 108, 1-28, 2000.

47) Siebenga, J.J. et al. : Norovirus illness is a global problem : emergence and spread of norovirus G II .4 variants, 2001-
2007. J. Infect. Dis., 200, 802-812, 2009.

48) Smiley, J.R. et al. : Characterization of an enteropathogenic bovine calicivirus representing a potentially new calicivirus genus. J. Virol., 76, 10089-10098, 2002.

49) Souza, M. et al. : Pathogenesis and immune responses in gnotobiotic calves after infection with the genogroup II .4HS66 strain of human norovirus. J. Virol., 82, 1777-1786, 2008.

50) Sugieda, M. et al. : Detection of Norwalk-like virus genes in the caecum contents of pigs. Arch. Virol., 143, 12151221, 1998.

51）田村 務ら：ノロウイルス G II/4 の新しい変異株の 遺伝子解析と全国における検出状況，IASR，33，333334, 2012.

52) Tan, M., Hegde, R.S. and Jiang, X. : The P domain of norovirus capsid protein forms dimer and binds to histoblood group antigen receptors. J. Virol., 78, 6233-6242, 2004.

53) van Beek, J. et al. : NoroNet.:Indications for worldwide increased norovirus activity associated with emergence of a new variant of genotype II .4, late 2012.Euro. Surveill., 18, 8-9, 2013.

54) van der Poel, W.H. et al. : Epidemiology of Norwalk-like virus infections in cattle in The Netherlands. Vet. Microbiol., 29, 297-309, 2003.

55) Vildevall, M. et al. : Human antibody responses to bovine (Newbury-2) norovirus (G III.2) and association to histoblood group antigens. J. Med. Virol., 82, 1241-1246, 2010.

56) Wang, Q.H. et al. : Porcine noroviruses related to human noroviruses. Emerg. Infect. Dis., 11, 1874-1881, 2005.

57) Widdowson, M.A. et al. : Detection of serum antibodies to bovine norovirus in veterinarians and the general population in the Netherlands. J. Med. Virol., 76, 119-128, 2005.

58) Wise, A.G. et al. : Molecular characterization of noroviruses detected in diarrheic stools of Michigan and Wisconsin dairy calves : circulation of two distinct subgroups. Virus Res., 100, 165-177, 2004.

59) Woode, G.N. and Bridger, J.C. : Isolation of small viruses resembling astroviruses and caliciviruses from acute enteritis of calves. J. Med. Microbiol., 11, 441-452, 1978.

60) Xi, J.N. et al. : Norwalk virus genome cloning and characterization. Science, 250, 1580-1583, 1990.

61）吉澄志磨ら：ノロウイルスによる胃腸炎集団発生につ いて一北海道, 2003/04 シーズン一, 北海道衛生研究 所所報, 54, 37-42, 2004.

62) Zakhour, M. et al. Bovine norovirus : carbohydrate ligand, 
environmental contamination, and potential cross-species transmission via oysters. Appl. Environ. Microbiol., 76, 6404-6411, 2010.

63) Zakhour, M. et al. : The $a$ Gal epitope of the histo-blood group antigen family is a ligand for bovine norovirus Newbury 2 expected to prevent cross-species transmission. PLoS
Pathog., 5, e1000504. doi : 10.1371/journal.ppat.1000504, 2009.

64) Zakikhany, K. et al. : Molecular evolution of G II -4 Norovirus strains. PLoS One., 7, e41625, 2012.

65) Zheng, D.P. et al. : Norovirus classification and proposed strain nomenclature. Virology, 346, 312-323, 2006. 